\title{
ARE GENDER PERSPECTIVES INCLUDED IN EDUCATION FOR SUSTAINABLE CONSUMPTION AND WASTE EDUCATION PROGRAMS? A SYSTEMATIC LITERATURE REVIEW
}

\section{Letícia Sarmento dos Muchangos ${ }^{1,2, \star}$ and Philip Vaughter ${ }^{1}$}

${ }^{1}$ UNU, Institute for the Advanced Study of Sustainability (UNU-IAS), Shibuya, Tokyo, Japan

${ }^{2}$ Keio University, Graduate School of Media and Governance, Fujisawa, Kanagawa, Japan

Article Info:

Received:

5 July 2018

Revised:

16 October 2018

Accepted:

24 October 2018

Available online:

22 November 2018

Keywords:

Bibliometric analysis

Education for sustainable

consumption

Gender

Perspectives

Systematic review

Waste education

\begin{abstract}
Education for sustainable consumption (ESC) has a role in the provision of knowledge, values, and skills to enable individuals and social groups to become actors of change towards more sustainable lifestyles. Also, it must consider the interests, needs, and perspective of critical stakeholders, empower them and enable their full participation in public debates about sustainability. Though unsustainable consumption is substantially shaped by gender-based inequalities, ESC itself tends to be gender-neutral. This study provides a systematic literature review of research on ESC, with a focus on waste education, and an assessment of the inclusion of gender perspectives in those publications. A structured tool Proknown-C was applied and 46 articles were retrieved and analyzed - 28 generally related to ESC and 18 to waste education in particular. The articles were published intermittently between 1990 and 2017, with case studies on 32 countries. From the aggregate number of articles, 22 addressed gender in some form, however, in its majority, it was limited to superficial mentions and to the presentation of the study subjects in a sex-disaggregated manner, with fewer exploring gender and its relationships with ESC and waste education. This study offers a contribution to the scholarly and practical debate on ESC and waste education programs, and the inclusion of gender perspectives, as well as, kindle in-depth research on the subjects. It also aims to provide points for better understanding the role of gender perspectives in promoting sustainable consumption practices and lifestyles.
\end{abstract}

\section{INTRODUCTION}

Unsustainable consumption and production is a tremendous environmental problem and is, therefore, a top priority for the global environmental agenda (UNEP, 2016). In 1992, resulting from the Rio de Janeiro UN Conference on Environment and Development, Sustainable Consumption and Production (SCP) was acknowledged as an all-embracing theme linking environmental and development challenges (UNEP, 2010). More recently, in the 2030 Agenda for Sustainable Development, SCP gained a central role for the achievement of sustainable development, reflected in its identification as a stand-alone Sustainable Development Goal (SDG 12) and also as a cross-cutting issue in many of the 17 goals and 169 targets adopted in the agenda (Ekins and Lemaire, 2012; Statistics Sweden, 2016). SCP relates to the use of products and services to respond to basic needs and provide a better quality of life, with minimal usage of natural resources, toxic materials, and emissions of by-products throughout the life cycle of those products or services, ultimately protecting the needs of future generations (UNEP, 2012).

Gender inequality issues are determinant and fundamentally shape unsustainable consumption and production practices (Sexsmith, 2012). This is particularly true in the consumption field, though consumer choices are also influenced by income level, social status and biases, however, gender is still a significant driver (OECD, 2008; Schultz and Stieß, 2009). Women tend to have less resource-intensive (and therefore more sustainable) lifestyles and display more pro-environmental attitudes, whether rich or poor, while men's consumption patterns and ecological footprint are usually greater than women's (Bulut et al., 2017; Chant, 2006; OECD, 2008). In addition, the gendering of non-sex-differentiated products and services is a standard marketing tool used to assign gender characteristics and increase demand and consumption for given products (UNEP, 2016). The Global Gender and Environment Outlook (2016) for instance, provide informative examples
* Corresponding author:

Letícia Sarmento dos Muchangos

email: leticia.muchangos@unu.edu 
of how femininity and masculinity norms steer meat, car and personal cosmetics' consumption. On the other hand, gender-based inequalities and social exclusion are key factors undermining people's ability to anticipate and prepare for major disasters, as well as; it shapes their susceptibility and exposure to the impacts of climate change (Le Masson, Norton, and Wilkinson, 2012). Women and girls' figure as more socially, economically and environmentally vulnerable to the effects of unsustainable consumption and production practices, such as extreme weather events and disasters. For example, studies have been reporting that climate change-related disasters and catastrophes, prompt gender-based impacts, with women and girls suffering from injuries, and diseases more than the men, as well as, being more prone to suffer abuse and sexual violence in post-disaster situations (OECD, 2008; Schultz and Stieß, 2009; Stevens, 2010).

To address the current global unsustainable consumption challenges, raising sustainability awareness in individuals is imperative. As such, education is indispensable (Avan, Aydinli, Bakar, and Alboga, 2011; McKeown, Hopkins, Rizi, and Chrystalbridge, 2006). As Stanszus et al. (2017) stated, "The nexus of education, consumption and sustainable development has been at the top of the agenda since the very inception of the political process towards sustainable development at the Rio Conference in 1992." Accordingly, Education for Sustainable Consumption (ESC) has the specific role of provisioning knowledge, values, and skills to enable individuals and social groups to become actors of change towards more sustainable consumption lifestyles. Consumers' rights are therefore integrated into ESC, in order to empower them and to enable their full participation in both public debate and the economy in an informed, confident and ethical way (Choi and Didham, 2009; Stanszus et al., 2017; UNEP, 2017).

Nevertheless, ESC is commonly gender-neutral and ignores gender-based inequalities, even though those same inequalities determine and aggravate unsustainable consumption practices (Gough, 2016; OECD, 2008; Sexsmith, 2012; Stevens, 2010). Despite the scholarly recognition of a gender influence in ESC, a state-of-the-art analysis is still lacking. As far as the authors understand, there are no systematic review studies that address ESD in general nor ESC and gender specifically.

This paper, therefore, presents an examination of the research developments around ESC, focusing on the subject of waste education and the inclusion of gender perspectives in waste education. Waste is a component of SCP and invariably a relevant theme of ESC (Thoresen, 2010; UNEP, 2010). Waste management is present in three targets of SDG 12 (United Nations, 2016):

- Target 12.3 By 2030, halve per capita global food waste at the retail and consumer levels and reduce food losses along production and supply chains, including post-harvest losses;

- Target 12.4 By 2020, achieve the environmentally sound management of chemicals and all wastes throughout their life cycle, in accordance with agreed international frameworks, and significantly reduce their release to air, water and soil in order to minimize their adverse impacts on human health and the environment;

- Target 12.5 By 2030, substantially reduce waste generation through prevention, reduction, recycling, and reuse.

The specific objectives of this study are to: (1) comprehend what is the current state of the research literature on ESC and waste education; (2) identify instances were publications include gender perspectives; and, (3) analyze the extent and specific content of these gender perspectives' inclusion.

\section{MATERIALS AND METHODS}

The purpose of a systematic literature review is to present a balanced and impartial summary of previous relevant and quality research to inform the researchers' decisions (Crombie and Davies, 2009). Compared with traditional literature review approaches, systematic review offers a structured review format, which is more transparent and replicable (Schulze, Nehler, Ottosson, and Thollander, 2016). Furthermore, a systematic review should encompass a comprehensive and systematic search for studies; an explicit and reproducible strategy for screening and including the studies, as well as, for data extraction; a detailed report and analysis of the results; and, a presentation of potential future pathways for research and practice (Caiado, de Freitas Dias, Mattos, Quelhas, and Leal Filho, 2017). To build up knowledge for the completion of this systematic review, an adaptation of the tool Knowledge Development Process intervention instrument - constructivist (ProKnow-C) was applied. Proknow-C was developed and presented in 2008, by the Laboratory of Multi-criteria Methodologies in Decision Support, from the Federal University of Santa Catarina in Brazil. The primary goal of such a tool is to aid in the process of selection and analysis of bibliographic material in a given subject, through a scientific process (Ensslin, Dutra, Ensslin, Chaves, and Dezem, 2015; Rosa, Petri, Matos, Ensslin, and Ferreira, 2015). Proknow-C follows a constructivist process that results in the formation of an in-depth understanding of the surveyed subject, based on the researcher's interests and limitations (Rosa et al., 2015). It aims to mainly address the lack of structure in the process of identification, selection, and analysis of bibliographic references with scientific recognition, in what relates to the connection between the research objectives and the alignment and relevance of the retrieved content (Ensslin et al., 2015). ProKnow-C application includes the following steps: (1) definition of the bibliographic portfolio (BP); (2) bibliometric analysis of the portfolio; (3) systemic analysis; and (4) definition of the research question and its objectives (Caiado et al., 2017; Ensslin et al., 2015; Viegas et al., 2016).

- For the BP definition (step 1), initially, four broadly recognized scientific electronic database were selected ERIC, Scopus, Science Direct, and ISI Web of Science (WoS), with the search procedure combining the search terms in the titles, abstracts, and keywords. Two search strings were followed: the term 'education for sustain- 
able consumption' corresponded to the ESC theme search, and the terms, 'waste education,' 'waste awareness,' 'waste teaching, and 'waste learning,' corresponded to the overall waste education theme search.

- Continuing with the BP definition, inclusion and exclusion criteria were applied to the results retrieved from the previous activity. In defining the BP, the intended subject for knowledge development is decided by the researcher (Ensslin et al., 2015). In this case, five criteria were selected: the type of publication; research discipline; relevance to the study, language, and availability. For the type of publication, only peer-reviewed academic journal articles were considered. This choice was based on the notion that those commonly retain a higher level of quality and are more readily available (Garza-Reyes, 2015; Schulze et al., 2016). For the research discipline, within the ESC string, no criterion was applied, while for waste education, articles related to the Waste Management discipline were included. On the relevance to the study, it was limited to studies addressing education programs (focusing on solid waste education for the waste education string), and excluded, for example, articles only reporting on education awareness levels, and articles with content outside of the scope, such as reports on waste characterization and generation estimations. The final two language, and availability, considered the inclusion of articles in English and Portuguese and articles where the full text was available online, with no time-period limitation. As a result, a total of 1996 articles were identified and initially stored in the reference management software, Endnote.

- Next, an automatic screening of duplicate articles in EndNote, followed by a manual screening of the titles and abstracts to check the alignment with the subject of interest resulted, in the exclusion of additional articles. The screenings yielded a total of 62 articles, which were downloaded for full-text analysis, resulting in the final number of 46 articles being used for the steps 2 and 3 of the Proknow-C tool respectively, and for the gender inclusion assessment.

A summary of the steps performed to select the papers of the BP is presented in the Table 1.

To assess the inclusion of gender perspectives in the $\mathrm{BP}$, a subsequent word search query within the 46 articles was completed, comprising the words, 'gender,' 'sex', 'woman,' 'women,' 'man,' 'men', 'male', 'female', 'girl(s)' and 'boy(s).' The bibliometric analysis and the gender perspective assessment were performed through qualitative data analysis, a task supported by the use of software QSR NVivo (QSR International Pty Ltd, 2017). The list of articles included in the literature review is displayed in Table 2.

\section{RESULTS AND DISCUSSION}

\subsection{Bibliometric analysis}

\subsubsection{Journal of publication}

Generally, the majority of the articles were published in Procedia - Social and Behavioural Sciences (9 articles), the International Journal of Environmental and Science Education (6 articles) and Waste Management (5 articles), with all articles found within the waste education string. The remainder English language journals and the two Portuguese language journals within the waste education string - Revista Eletrônica de Administração and Cadernos EBAPE.BR, each presented one article (Figure 1). For the ESC string, five articles were published in Procedia Social and Behavioural Sciences, while three articles were in the International Journal of Environmental and Science Education.

\subsubsection{Distribution across time and geographical focus}

The articles were found to be fragmented in time and location. The publication period spanned from 1990 to 2017, with 2016 presenting the highest number of publications ( 9 articles), while no publication was found for eight consecutive years in the 1990s (1991-1998), nor for seven consecutive years in the early 2000s (2000-2006), and none in 2010 (Figure 2). Most publications occurred after 2010, with all articles in 2012 addressing ESC, with and all articles in 2014 doing the same, followed by four publications on ESC in both 2016 and 2017. Individually for waste education, the earliest publication was in 2007, and most articles were published on this topic in 2013 and 2016, four and five articles, respectively. In almost three decades, more than $80 \%$ of all articles were published in the period between 2011 and 2017. The steady increase of research studies on this years can likely be linked to the outcomes of the UN Decade of Education for Sustainable Development (2005-2014), declared in 2002, followed by the launch of the UNESCO's Global Action Programme (GAP) in 2014, as well as from the global adoption of the SDGs (UNESCO, 2007, 2014; United Nations, 2016).

The distribution across continents of study locations, suggests a global interest in the subject, mainly from higher-income economies, such as the United States of America, United Kingdom, Germany, Italy, and Australia. Middle-income economies such as Indonesia, Malaysia, and Brazil, had two articles each, all focusing on waste education, except Turkey, which had one article on ESC and another on waste education. The remaining locations

TABLE 1: Literature search process.

\begin{tabular}{|c|c|c|}
\hline & $\begin{array}{l}\text { Education for sustainable } \\
\text { consumption }\end{array}$ & $\begin{array}{l}\text { Waste } \\
\text { Education }\end{array}$ \\
\hline Databases & \multicolumn{2}{|c|}{ Eric; ScienceDirect, Web of Science; Scopus } \\
\hline \multirow[t]{2}{*}{$\begin{array}{l}\text { Abstract, Title, } \\
\text { Keywords }\end{array}$} & $\begin{array}{l}\text { education for } \\
\text { sustainable } \\
\text { consumption }\end{array}$ & $\begin{array}{l}\text { waste education, waste } \\
\text { awareness, waste teach- } \\
\text { ing, waste learning }\end{array}$ \\
\hline & 9,157 & 20,375 \\
\hline $\begin{array}{l}\text { Criteria for inclu- } \\
\text { sion/exclusion }\end{array}$ & 976 & 1020 \\
\hline $\begin{array}{l}\text { Exclusion of } \\
\text { duplicates and } \\
\text { Title and } A b- \\
\text { stract review }\end{array}$ & 32 & 30 \\
\hline Full-text analysis & 28 & 18 \\
\hline Final results & \multicolumn{2}{|c|}{46} \\
\hline
\end{tabular}


TABLE 2: Articles analyzed in the review.

\begin{tabular}{|c|c|c|}
\hline Authors & Keywords & ESC Theme specific / Waste type \\
\hline (Brumby et al., 2011) & $\mathrm{N} / \mathrm{A}$ & Alcohol consumption \\
\hline (Çelikler and Harman, 2015) & $\begin{array}{l}\text { SCAMPER technique; Solid waste; Awareness; } \\
\text { Science student }\end{array}$ & Solid waste \\
\hline (Chalfoun, 2014) & $\begin{array}{l}\text { Campus greening; energy efficiency; energy } \\
\text { simulation; hands-on education }\end{array}$ & Energy conservation and efficient use \\
\hline (Chandra, 2014) & $\begin{array}{l}\text { Environmental education for sustainability; } \\
\text { Indigenous perspectives; Sustainable develop- } \\
\text { ment; Traditional ecological knowledge; Western } \\
\text { science }\end{array}$ & Traditional knowledge \\
\hline (Crawford, Luke and Van Pelt, 2015) & $\begin{array}{l}\text { Curriculum; inquiry; environmental sustainability; } \\
\text { plastic pollution; global citizenship; STEM }\end{array}$ & Packaging \\
\hline (Danilane and Marzano, 2014) & $\begin{array}{l}\text { Consumer education; consumer education; } \\
\text { social learning theories; ducat; education for sus- } \\
\text { tainable development; social learning theories }\end{array}$ & Consumer education \\
\hline (Davis, 2008) & $\mathrm{N} / \mathrm{A}$ & Waste management \\
\hline (Finlayson et al., 2017) & $\begin{array}{l}\text { Undergraduate research; Pedagogy; Case study; } \\
\text { Food waste; Agriculture }\end{array}$ & Food waste \\
\hline (González-Gaudiano, 1990) & N/A & $\begin{array}{l}\text { Development of environmental education for } \\
\text { sustainable consumption }\end{array}$ \\
\hline (Gough and Scott, 1999) & $\mathrm{N} / \mathrm{A}$ & Tourism \\
\hline (Hadiyanti, 2016) & $\begin{array}{l}\text { A group approach; Empowerment; Waste } \\
\text { recycling }\end{array}$ & Household waste \\
\hline (Hadjichambis et al., 2015) & $\begin{array}{l}\text { Decision-making; Environmental education pro- } \\
\text { gram; Environmental representations; Sustain- } \\
\text { able consumption }\end{array}$ & Consumer education \\
\hline (Hawas and Al-Habaibeh, 2017) & $\begin{array}{l}\text { Building energy efficiency; education; innova- } \\
\text { tion; public engagement; simulation; thermal } \\
\text { performance }\end{array}$ & Energy \\
\hline (Indrianti, 2016) & $\begin{array}{l}\text { Household waste; Waste bank; Sustainable; } \\
\text { Education; Quran education park }\end{array}$ & Household waste \\
\hline (Kamaruddin, Pawson and Kingham, 2013) & $\begin{array}{l}\text { Social learning; Sustainable waste management; } \\
\text { NGO }\end{array}$ & Municipal solid waste \\
\hline (Kanchanabhandhu and Woraphong, 2016) & $\begin{array}{l}\text { Model; solid waste management; Multilateral co- } \\
\text { operation; Semi-urban community }\end{array}$ & Solid waste \\
\hline (Kearns et al., 2013) & learning cities; learning festivals; lifelong learning & Learning festivals \\
\hline (Kossieris, Kozanis, et al., 2014) & $\begin{array}{l}\text { Analytics; End-user; ICT; Smart metering; Urban } \\
\text { water management; Water-energy nexus; Web } \\
\text { Implementations }\end{array}$ & Water \\
\hline (Kossieris, Panayiotakis, et al., 2014) & $\begin{array}{l}\text { E-learning; Moodle platform; Online Implemen- } \\
\text { tation; Online education; Smart metering; Water } \\
\text { demand management; Water efficiency }\end{array}$ & Water \\
\hline (Kumar, Somrongthong and Shaikh, 2015) & $\begin{array}{l}\text { Health care workers; Waste management; Infec- } \\
\text { tious waste; KAP; Quasi-experimental study }\end{array}$ & Intensive Healthcare waste \\
\hline (Nowak et al., 2009) & $\begin{array}{l}\text { Community-based eco-pedagogy; Eco-centered } \\
\text { Early Childhood Education; Parent involvement } \\
\text { Introduction }\end{array}$ & Consumer education \\
\hline (Leger and Pruneau, 2012) & $\begin{array}{l}\text { Climate change mitigation; environmental behav- } \\
\text { ior; environmental competences; environmental } \\
\text { education; family systems }\end{array}$ & Climate change \\
\hline (Maddox et al., 2011) & $\begin{array}{l}\text { Waste management; Recycling; Environmental } \\
\text { education; Sustainability; Intergenerational } \\
\text { influence }\end{array}$ & Household waste \\
\hline (Mostowfi, Mamaghani and Khorramar, 2016) & $\begin{array}{l}\text { Board game; Fun toolkit; Children psychology; } \\
\text { Educational game; Environmental education; } \\
\text { Recycle game }\end{array}$ & Household waste \\
\hline (Nagata et al., 2014) & $\begin{array}{l}\text { Customer involvement; Platform for consumer } \\
\text { and suppliers; Rebuild relationship between } \\
\text { consumers and retaile }\end{array}$ & Supply chain: Retailert-Consumer \\
\hline (Nowak et al., 2009) & $\mathrm{N} / \mathrm{A}$ & Product life cycle and traceability \\
\hline (Oliver, 2016) & $\begin{array}{l}\text { Carbon footprint; Case study; Environmental } \\
\text { behavior; Role-play; Transformative learning }\end{array}$ & Carbon footprint \\
\hline
\end{tabular}




\begin{tabular}{|c|c|c|}
\hline Authors & Keywords & ESC Theme specific / Waste type \\
\hline (Oto, Cobanoglu and Geray, 2012) & $\begin{array}{l}\text { Environmental bioethics; environmental educa- } \\
\text { tion; environmental sustainability; sustainable } \\
\text { airport }\end{array}$ & Environmental bioethics \\
\hline (Painter, Thondhlana and Kua, 2016) & $\begin{array}{l}\text { Food waste; Universities; Interventions; Food } \\
\text { waste prevention; South Africa }\end{array}$ & Food waste \\
\hline (Pankina et al., 2016) & $\begin{array}{l}\text { Consumer culture; design; ecological design; } \\
\text { ecological culture; ethics of design }\end{array}$ & Consumer education \\
\hline (Patterson et al., 2009) & $\mathrm{N} / \mathrm{A}$ & Conservation of natural resources \\
\hline (Pérez-Belis, Bovea and Simó, 2015) & $\begin{array}{l}\text { Waste electrical/electronic equipment; WEEE; } \\
\text { Environmental education; Toy Survey }\end{array}$ & Waste electrical and eletronic equipment \\
\hline (Polanec, Aberšek and Glodež, 2013) & $\begin{array}{l}\text { Awareness; Educational concept; Adult educa- } \\
\text { tion; Microtraining; Waste management }\end{array}$ & Solid waste \\
\hline (Radulescu and Radulescu, 2011) & $\begin{array}{l}\text { Consumer; Education; Healthy environment; } \\
\text { Right to a healthy environment }\end{array}$ & Marketing \\
\hline (Redman, 2013) & $\begin{array}{l}\text { Sustainability education; Transformative change; } \\
\text { Pro-environmental actions; Sustainability } \\
\text { competencies; environmentally responsible } \\
\text { consumption }\end{array}$ & Household waste \\
\hline (Ribas et al., 2017) & $\begin{array}{l}\text { Social Responsibility Environmental Manage- } \\
\text { ment; Environmental Marketing }\end{array}$ & Solid waste \\
\hline (Roeder, Scheibleger and Stark, 2016) & $\begin{array}{l}\text { Self-perception theory; social labelling; sustain- } \\
\text { ability communication; teaching method }\end{array}$ & Sustainable manufacturing \\
\hline (Ruini et al., 2016) & $\begin{array}{l}\text { Carbon footprint; ecological footprint; mediterra- } \\
\text { nean diet; sustainability }\end{array}$ & Food consumption \\
\hline (Schreinemachers et al., 2017) & $\begin{array}{l}\text { Education; Food behavior; Impact evaluation; } \\
\text { Malnutrition; Nutrition-sensitive agriculture; } \\
\text { Randomized controlled trial; Vegetables }\end{array}$ & Food and sustainable agriculture \\
\hline (Stanszus et al., 2017) & $\begin{array}{l}\text { curriculum development; education for sustain- } \\
\text { able consumption; ethics; intervention design; } \\
\text { mindfulness; mindfulness-based stress reduc- } \\
\text { tion; sustainable consumption; values }\end{array}$ & Mindfullness \\
\hline (Traversa et al., 2017) & Children; food safety; nutrition & Food \\
\hline (Vieira and Echeverria, 2007) & $\begin{array}{l}\text { Public administration; Environmental education; } \\
\text { Sustainability; Urban development }\end{array}$ & Municipal solid waste \\
\hline (Wahba, 2012) & $\begin{array}{l}\text { Environmental Advertising; Green Advertising; } \\
\text { Greenwashing Advertising; Think Sustainability }\end{array}$ & Advertising design \\
\hline (Yang, Chien and Liu, 2012) & $\begin{array}{l}\text { Foreign Countries; Learning Motivation; Learning } \\
\text { S; Taiwan }\end{array}$ & Energy conservation \\
\hline (Zain et al., 2013) & $\begin{array}{l}\text { Sustainable; Entrepreneurship; Education; Innova- } \\
\text { tion; } 3 \mathrm{R}\end{array}$ & Municipal solid waste \\
\hline (Zarate, Slotnick and Ramos, 2008) & $\mathrm{N} / \mathrm{A}$ & Household waste \\
\hline
\end{tabular}

identified had one article each, with two articles not being location-specific. Moreover, despite the broad geographic distribution, only one article focused on cross-country research - a case study comparing Canada and the Solomon Islands (Figure 3).

\subsection{Content analysis}

Figure 4 presents a summary of the main findings of the content analysis, described in the following sub-sections.

\subsubsection{Study methodologies}

The study methodologies applied were also analyzed according to the application of quantitative, qualitative or mixed research methods. Commonly, for quantitative methods, the emphasis is on techniques such as descriptive statistics, regression models and parametric analysis. On the other hand, techniques that characterize qualitative methods include literature review, media analysis, case studies, interviews and focus groups, his- torical and ethnographic analysis, theory, and discourse analysis (Aikens, McKenzie, and Vaughter, 2016; Caiado et al., 2017; Palomo, Figueroa-Domecq, and Laguna, 2017; Schulze et al., 2016).

None of the retrieved articles used only quantitative methods. A total of 31 articles (68\%), presented qualitative methodologies and 15 articles (32\%) had a combination of quantitative and qualitative and methods - a mixed methodology.

The majority of articles reported on education initiatives - programs, workshops, frameworks, web tools, and field experiments (36 articles). These included either all phases of the initiative (problem description/background, design, implementation, and evaluation of results), a combination of some of the phases, or a description of a single phase. For instance, in six articles the focus was on the design process of programs, frameworks, or a lesson plan (Hadiyanti, 2016; Kossieris, Panayiotakis, et al., 2014; Leger and Pruneau, 2012; Nowak, Hale, Lindholm, and Strausser, 


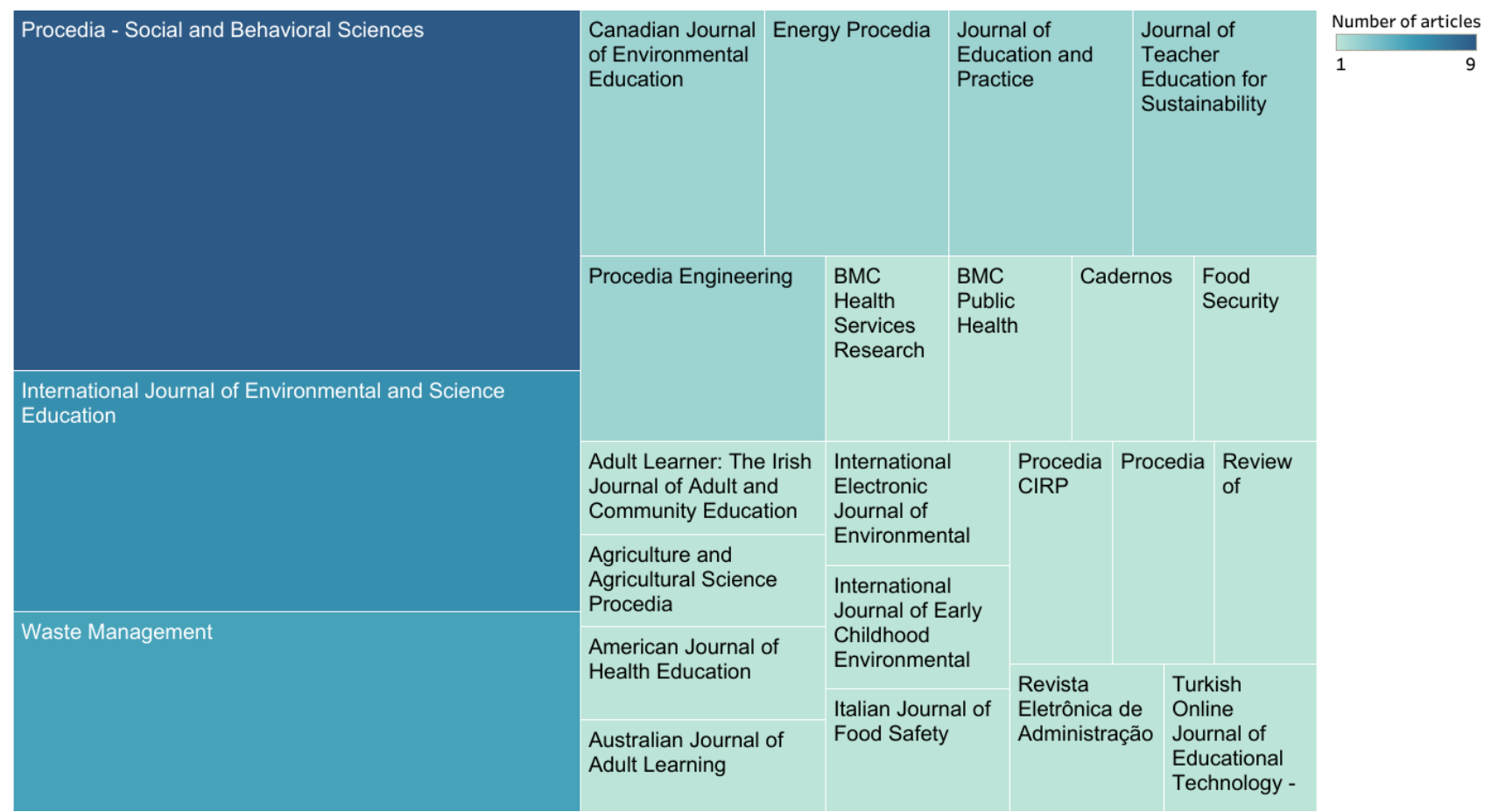

FIGURE 1: Number of articles per journal.

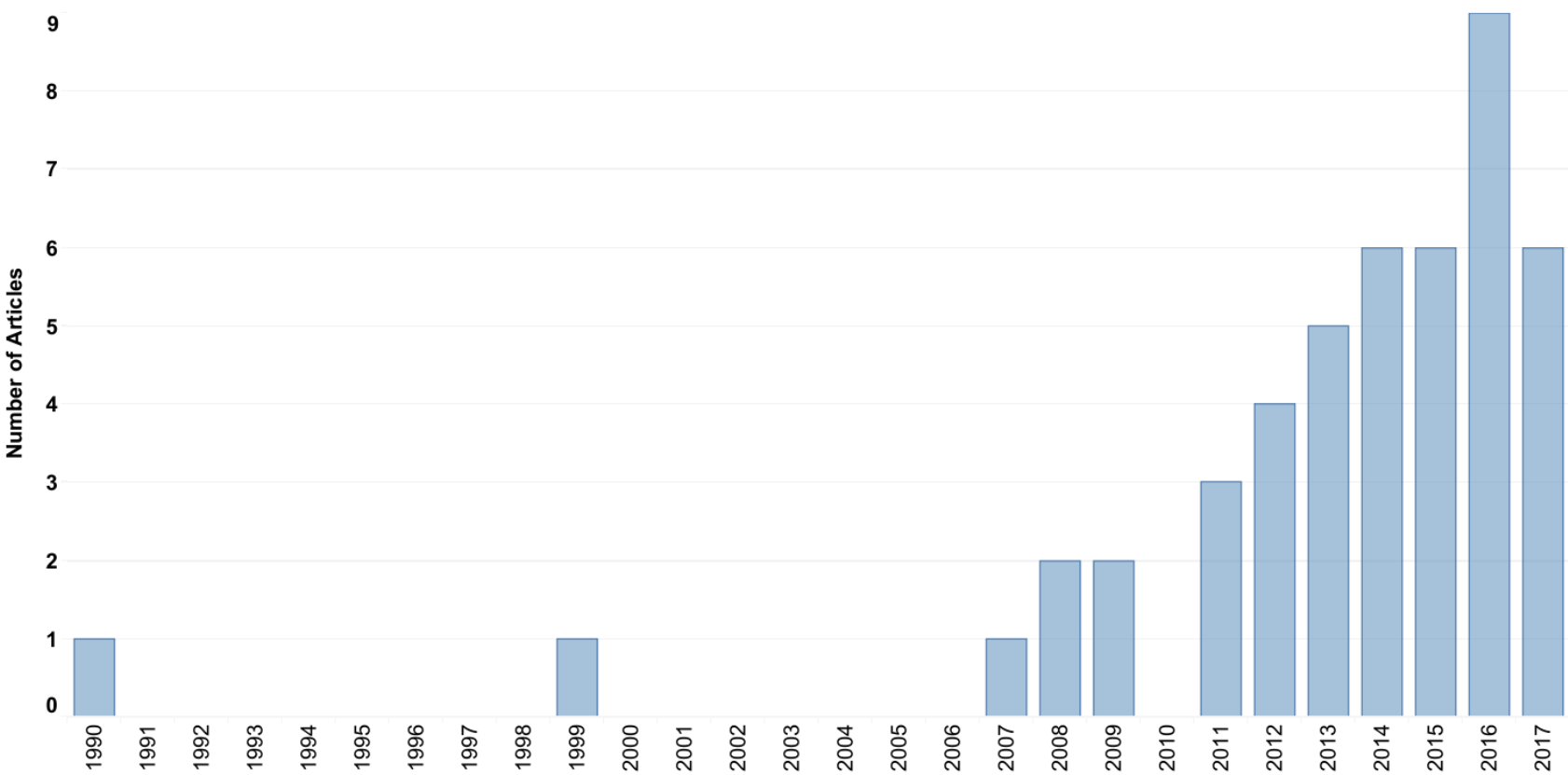

FIGURE 2: Articles published from 1990 to 2017.

2009; Polanec, Aberšek, and Glodež, 2013; Ribas, Vicente, Altaf, and Troccoli, 2017). There were also literature review studies, at times resulting in curriculum development and methodology proposals (Chandra, 2014; Davis, 2008; Oto, Cobanoglu, and Geray, 2012; Stanszus et al., 2017; Wahba, 2012). The remaining articles include a policy framework analysis, problem evaluations, the description of the implementation of a theoretical framework, and cultural and historical analysis (González-Gaudiano, 1990; Painter, Thondh- lana, and Kua, 2016; Pankina, Khrustalyova, Egarmin, and Shekhova, 2016; Ruini et al., 2016; Vieira and Echeverria, 2007).

\subsubsection{Type of education and thematic focus}

The classification for types of education was based on the OECD definition of forms of learning: formal, non-formal and informal learning (Organisation for Economic Co-operation and Development (OECD), 2005): 


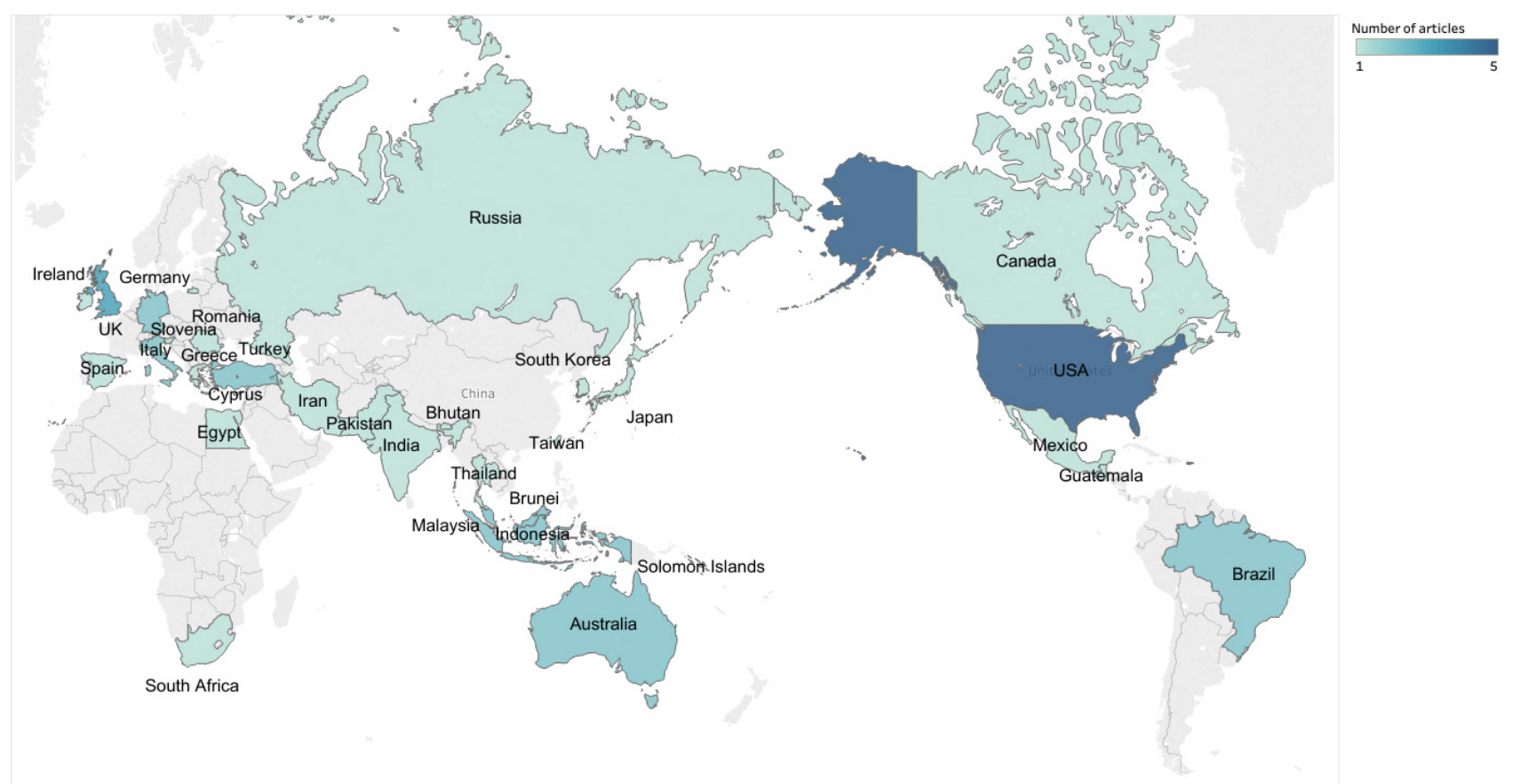

FIGURE 3: Geographical focus of the studies.

- Formal learning is usually related to an educational institution or an enterprise that offers formal education and training programs, guided by a formal curriculum; it leads to a recognized completion certificate or degree;

- Non-formal learning refers to organized instruction programs that occur in educational or labor settings, guided or not by a formal curriculum, but does not lead to a formal qualification;

- Informal learning, which is the result of daily work-related, family or leisure activities, occurs outside of organized education or training provision, hence, not leading to certification; it is often referred to as 'experience' or 'unintentional learning', happening throughout life without the learner necessarily being aware of the knowledge or skill gained.

Concerning the thematic focus, all articles were grouped according to the ten themes of ESC, as introduced by Thoresen (2010): Life quality; Lifestyles; Resources; Economics; Consumption and the environment; Consumer rights and responsibilities; Information management; Health and safety; Change management and Global awareness. Also, articles specific to waste education, which is part of ESC's Consumption and the environment theme, were further examined according to the waste type targeted.

An equal number of articles focused on formal and non-formal education - 15 articles each; six articles focused on the combination of non-formal and informal; three articles focused on the combination of formal and informal; two articles on the combination of formal and non-formal education, two articles on the combination of all types of education; and three articles did not specify the education type's focus.

The formal education articles spanned from primary to tertiary levels with one study inclusive of faculty members as target subjects. These articles covered several ESC topics such as sustainable tourism, product lifecycle, energy conservation and efficiency, consumer education, packaging, carbon footprint and food (Chalfoun, 2014; Crawford, Luke, and Van Pelt, 2015; Danilane and Marzano, 2014; S. Gough and Scott, 1999; Hawas and Al-Habaibeh, 2017; Nowak et al., 2009; Oliver, 2016; Pankina et al., 2016; Traversa et al., 2017). Specifically in the waste education field, two articles addressed food waste, while the remaining articles addressed household waste, municipal solid waste, and solid waste in general (Çelikler and Harman, 2015; Davis, 2008; Finlayson, Gregory, Ludtke, Meoli, and Ryan, 2017; Maddox, Doran, Williams, and Kus, 2011; Painter et al., 2016; Redman, 2013; Zain et al., 2013).

As for the articles on non-formal education, these addressed different societal segments, including the local community in household waste management and natural resource conservation (Hadiyanti, 2016; Indrianti, 2016; Patterson, Lindén, Edward, Wilhelmsson, and Löfgren, 2009); the public and private sectors in environmental bioethics and food consumption (Oto et al., 2012; Ribas et al., 2017; Ruini et al., 2016); health professionals dealing with alcohol consumption issues and healthcare waste management (Brumby et al., 2011; Kumar, Somrongthong, and Shaikh, 2015); household water end-users (Kossieris, Kozanis, et al., 2014; Kossieris, Panayiotakis, et al., 2014); consumers and retailers (Nagata, Azuma, Oda, Fujiwara, and Hanya, 2014); the general public on solid and municipal solid waste management (Kamaruddin, Pawson, and Kingham, 2013; Polanec et al., 2013); and, studies directed 
to youth from middle school age (Hadjichambis, Paraskeva-Hadjichambi, Ioannou, Georgiou, and Manoli, 2015), to university age (Yang, Chien, and Liu, 2012).

Concerning the combination of non-formal and informal education, the majority dealt with ESC topics in general, such as awareness raising for teens on sustainable manufactured products (Roeder, Scheibleger, and Stark, 2016), climate change issues at the community level (Roeder et al., 2016), consumer literacy for parents in South Korea (Lee, Jo, and Lim, 2015), and the discussion on the relevance of learning festivals for urban citizens, with Ireland as case study (Kearns, Lane, Neylon, and Osborne, 2013). On the other hand, articles on waste education specifically were targeting communities for household waste (Zarate, Slotnick, and Ramos, 2008), and solid waste management (Kanchanabhandhu and Woraphong, 2016).

The combination of formal and informal education and the formal and non-formal education produced three and two articles, respectively. The former combination included topics on household waste management for youth in the community (Redman, 2013), and waste electrical and electronic equipment management for children and parents (Pérez-Belis, Bovea, and Simó, 2015), in addition to, an article on the relevance of traditional knowledge inclusion in the Western environmental education (Chandra, 2014). For formal and non-formal education, articles took up the topic of mindfulness in ESC, with university students and employees as target subjects (Stanszus et al., 2017), as well as household waste management for elementary and middle school students (Mostowfi, Mamaghani, and Khorramar, 2016).

All forms of education combined were present in two articles, one on ESC for food and sustainable agriculture for children, parents and local the community (Schreinemachers et al., 2017), and one on waste management to evaluate a local education program (Vieira and Echeverria, 2007).

Lastly, in three of the articles reviewed, it was not explicitly stated the education type focus, with one focusing on information management and consumer rights and responsibilities, (Radulescu and Radulescu, 2011), another focusing on information management targeting Egyptian environmental designers (Wahba, 2012), and the other reporting on the status of ESC in Mexico (González-Gaudiano, 1990). Figures 4 to 6 , present the main findings of the content analysis for the 46 articles.

\subsection{The inclusion of Gender perspectives}

As the result of the word search of the terms presented in the Materials and Methods section, the inclusion of gender perspectives could be seen in a total of 22 out of 46 articles, 12 corresponding to ESC and ten corresponding to waste education.

\subsubsection{The landscape of the gender perspectives' inclusion}

The inclusion of gender in the set of 22 articles, can be observed in 2009, 2011-2014 with two articles per year, followed by a spike between 2015-2016, with four and seven articles respectively, and a retraction in 2017 with only two articles. As for the publications, the International Journal of Environmental and Science Education and Procedia - Social and Behavioural Sciences had five and four articles each, followed by two publications each from the Waste Management Journal and the Journal of Education and Practice. The remaining journals presented one article each.

Geographically, the study areas were diverse, with articles distributed almost evenly between the Global South and North (See Figure 8). Generally, the education programs described in 19 articles which an audience was identified were directed to four large target groups - Children (including parents); Community (including the general public and household users); Professionals (from the health sector and environmental designers); and Youth. Most of the subjects referred to the ESC themes, Consumption and the Environment, Lifestyles, Resources, and Information management.

\subsubsection{Gender focus and Language}

In five of the articles, gender was generally mentioned to contextualize, describe and give examples of aspects that were relevant to the study the authors were reporting on (Chandra, 2014; Kamaruddin et al., 2013; Pérez-Belis et

\section{ESC Theme}

Consumption and the environment - Waste education

Consumption and the environment

Information management

Consumption and the environment; Information management

Consumption and the environment; Lifestyles

Life quality; Lifestyles

Change management; Information management

Consumer rights and responsibilities; Information managemen

Consumption and the environment; Change management

Consumption and the environment; Change management; Information management

Consumption and the environment; Economics; Resources

Consumption and the environment; Health and Safety; Information management; Lifestyles Consumption and the environment; Health and Safety; Life quality

Consumption and the environment; Information management; Lifestyles; Resoucers

Consumption and the environment; Lifestyles; Resources

Consumption and the environment; Resources

General (all themes)

Health and Safety; Life quality; Lifestyles

Health and safety; Life quality; Lifestyles; Resources

Information management; Global awareness; Lifestyles

Information

Lifestyles

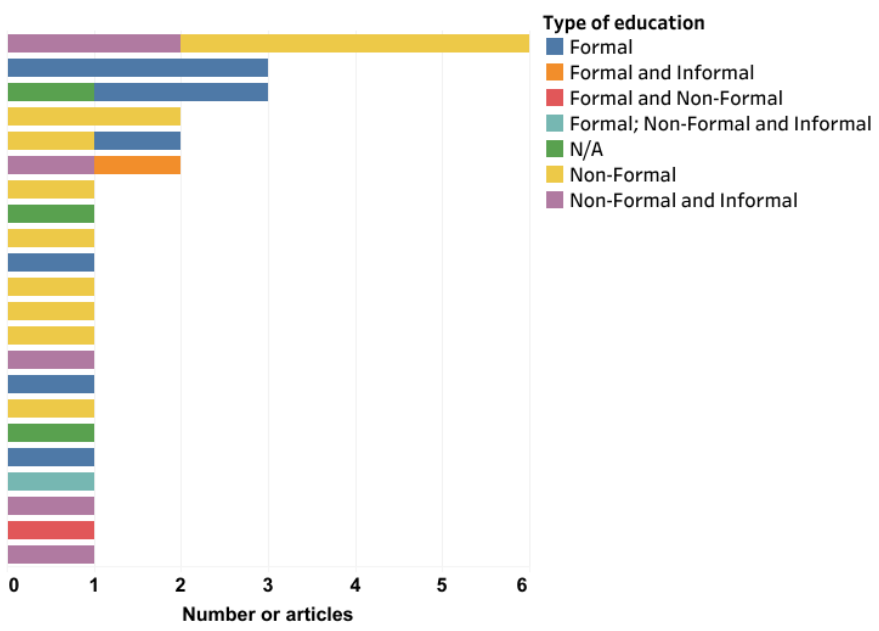

FIGURE 4: ESC themes and type of education. 


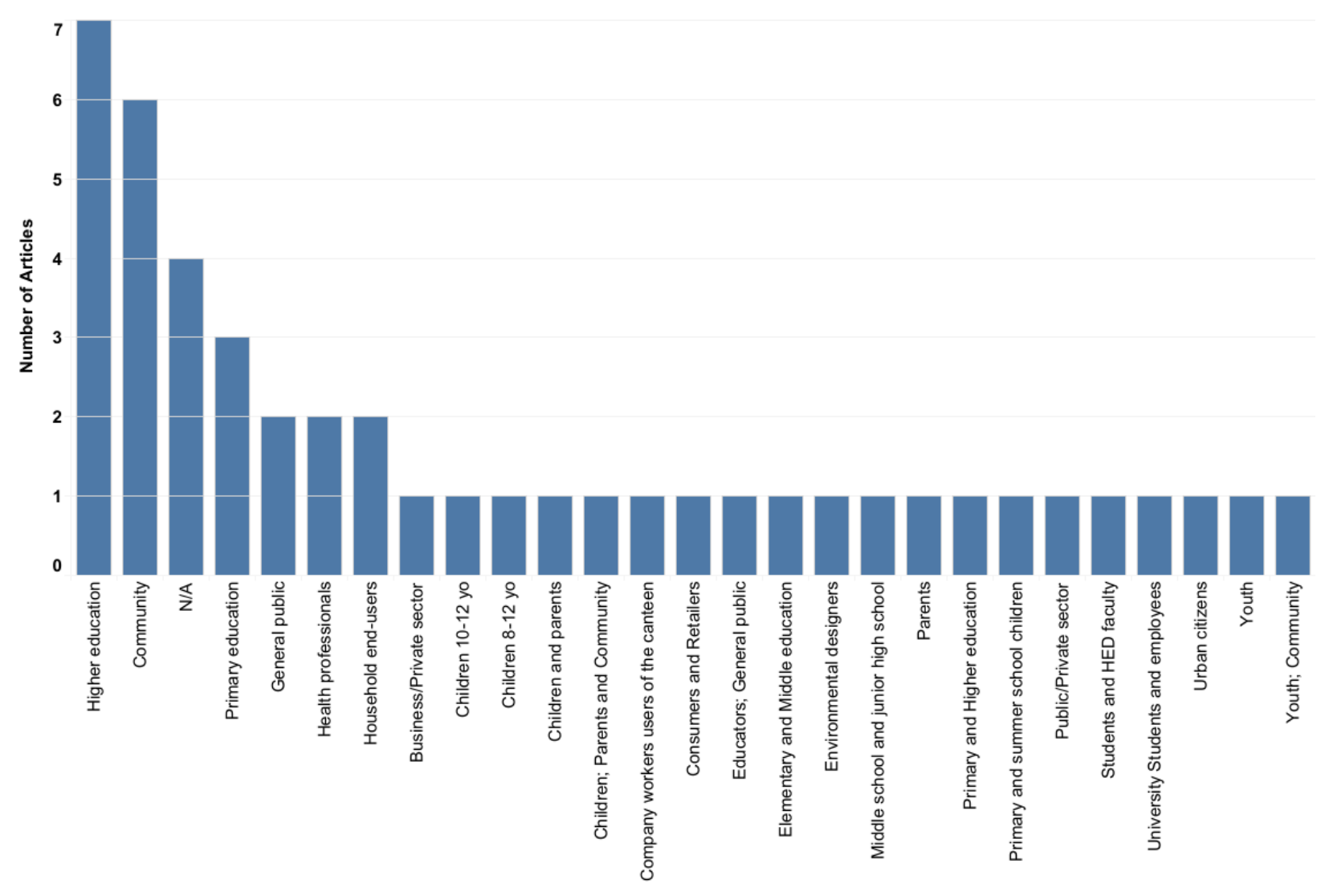

FIGURE 5: Target groups.
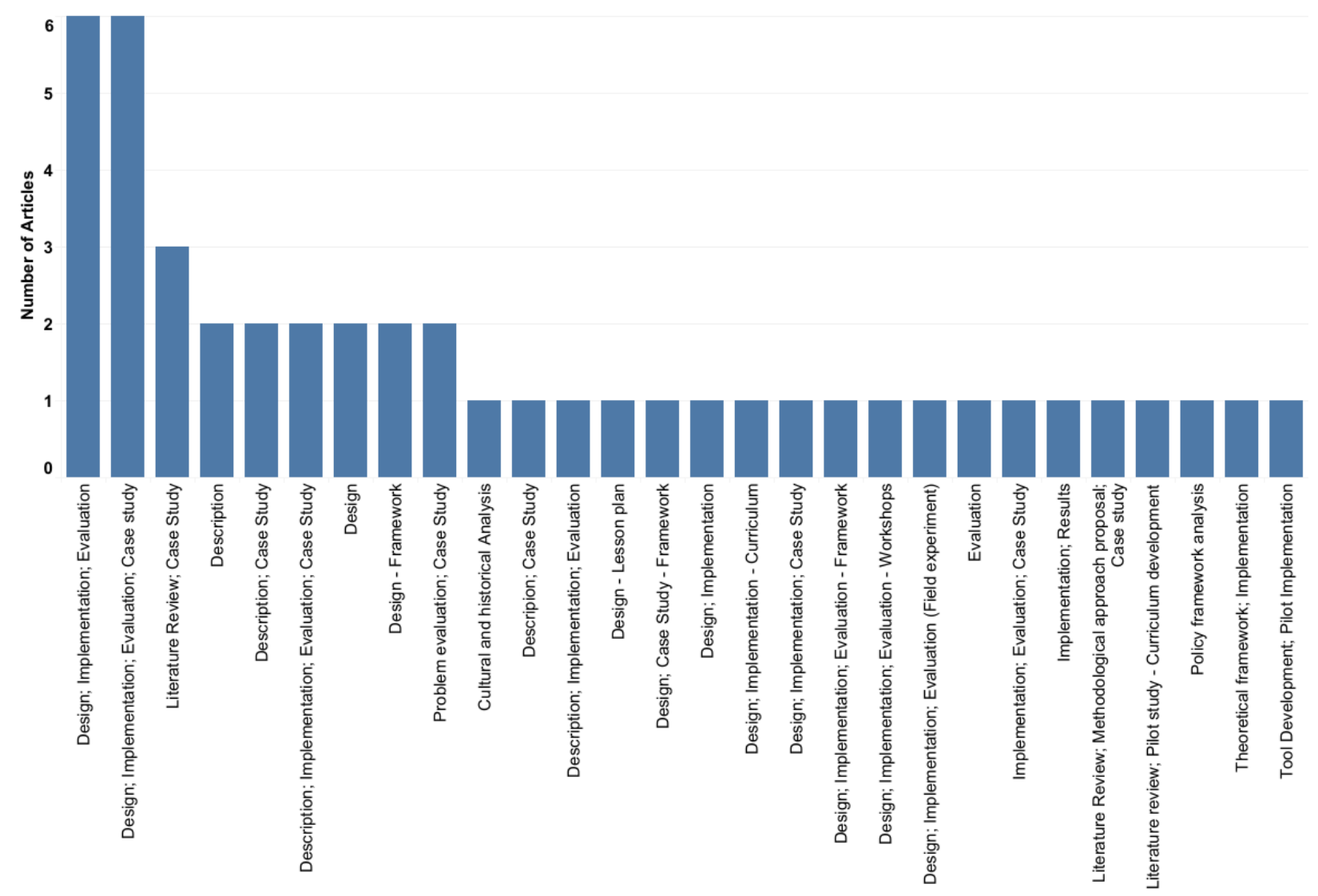

FIGURE 6: Research techniques. 

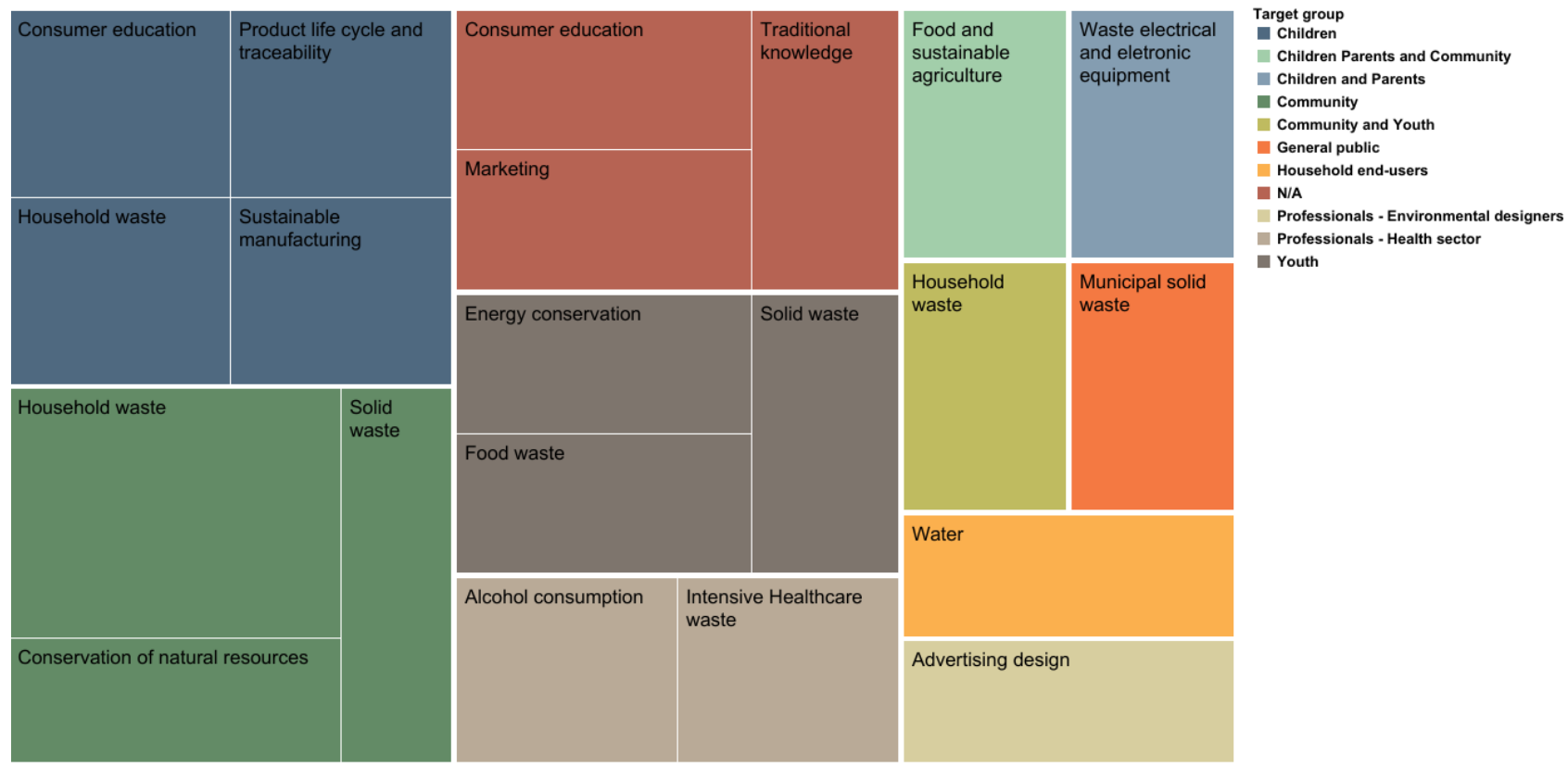

FIGURE 7: Articles including gender perspectives: Target groups and ESC sub-themes.

al., 2015; Roeder et al., 2016; Wahba, 2012). In an additional article, the authors also mentioned the suitability of the education program they were proposing, to "both boys and girls" (Mostowfi et al., 2016). In another set of articles, gender was solely included to describe the composition of the studied groups, qualitatively and quantitatively. That was the case in Yang et al. (2012), mentioning the student participants, testing their proposed digital game system to aid in energy conservation education; for a gender differentiation of the study subjects as well as their parents' education level in Çelikler and Harman (2015); and, in Kossieris, Panayiotakis, et al. (2014), on "sex", being one of the several socio-demographic characteristics included in the semi-structured interviews conducted.

On the usage of language, four articles displayed ambiguity issues where the authors did not clarify if they were referring to one or both sexes. For instance, expressions such as "man-made," "man and the environment" and "known to man," were used (Hadjichambis et al., 2015; Nowak et al., 2009; Pankina et al., 2016; Radulescu and Radulescu, 2011). On the contrary, the distinction of (farm) men and women is seen throughout Brumby et al.'s (2011) work, to describe a training program for health professionals dealing with alcohol misuse in farm families. Precise language use, considering aspects related to gender neutrality versus specificity, is pertinent to avoid injustices and discrimination issues. Particularly in the field of education, in 1987, a call was made to UNESCO for the avoidance of gender-specific language, as a result of the growing awareness of the power of language. The agreed premise is that "If words and expressions that imply that women are inferior to men are constantly used, that assumption of inferiority tends to become part of our mindset" (UNESCO, 1999). For instance, it has been widely reported that research and practice in education (particularly in environmental education), has been centered in the male experience or has seen them as universal subjects without differentiating between male and female, even if "man" is not a universal and dominant agent on the environment (Gough, 2003, 2013; UNESCO, 1999).

\subsubsection{Female and male stereotypes}

In one of the articles, the author briefly discussed that through comparison of the subjects' reactions, female participants exhibited a higher emotional response to the education program compared with their male counterpart. The author raised the possibility that this difference, was related to the notion that "women react more emotionally to environmental problems, which coupled with an internal locus of control (or enhanced effectiveness knowledge) will likely to lead to acting pro-environmentally" (Redman, 2013). The rhetoric described in the article, raises an issue that has been brought up by other researchers, which points to the fact that more concerned pro-environmental discourses and attitude towards green consumer behavior, are more gender-available to girls, than to boys (Autio, Heiskanen, and Heinonen, 2009; Blenkinsop, Piersol, and Sitka-Sage, 2017). Predominantly in Western culture, women have been assigned specific attributes related to nurturing skills and tolerance, and while these traits are likely to be developed as a result of the cultural assignment, it then creates a self-fulfilling prophesy cycle, in which the onus of upkeeping sustainability, and caring and protecting the environment is more significant for women (Autio et al., 2009; Jolley and Shields, 2009; March, Smyth, and Mukhopadhyay, 1999).

\subsubsection{Gender influence and the role of women}

The distinctive role of gender was discussed in seven articles.

While Redman (2013) considered how social norms were likely to dictate the gender differences regarding the subjects of the study's willingness to adopt a lower meat 
diet, Pankina et al. (2016), included gender as an indicator for the consumer market of everyday products.

More extensively, Kanchanabhandhu and Woraphong (2016) and Kumar et al. (2015), included gender-specific analysis of the level of knowledge, awareness, and participation, before and after the education program's implementation, for a model of solid waste management and for a training model for healthcare waste, respectively. Apart from describing the design and implementation processes, the authors also relied on statistical tools to calculate the different indicators of knowledge, awareness and practice changes.

A similar emphasis on statistics to analyze the difference in the impact of the program for boys and girls was reported in a school gardening intervention for sustainable food consumption and agriculture practices in Bhutan (Schreinemachers et al., 2017). Additionally, an investigation of food waste reduction in a South African university campus, together with data collection, sampling, and analysis in a sex-disaggregated medium, was completed. As an outcome, the authors argued that focus on gender should be a central requirement in setting up the interventions to reduce food waste generation, as well as, the necessity for it to be the focus for future research (Painter et al., 2016).

Lastly, a single article fully addressed the significance of assessing gender aspects characterizing the education program's targets subjects and used those to inform the strategies and resource allocation, along with the design and implementation of the program. Patterson et al. (2009), reported on an adult environmental education program targeting fisherwomen as the result of a preliminary analysis. The analysis elucidated that in the target area: women's self-help groups were in place working on the community's sustainable use of financial resources; a low level of awareness on the importance of coral reefs was prevalent among fisher people, particularly the fisherwomen; and, women were in a better position to influence male fishers, and children in the household. The importance of conducting a needs assessment including the existing gender profile, before the program development, has been recognized as a success factor in the development of appropriate interventions, particularly in sustainability-related issues (Aguilar, 1999; European Institute for Gender Equality, 2016; March et al., 1999).

Additionally, the acknowledgment of women as particularly influential in shaping sustainable consumption and waste management initiatives was stated in a couple of articles. Hadiyanti (2016), mentioned the presence of homemakers and working women, part of a community group engaged in a recycling project; while Indrianti (2016) discussed the role of a women's group in initiating and maintaining a waste bank project (Figure 8).

\section{CONCLUSIONS AND FUTURE RESEARCH OPPORTUNITIES}

This study provides the first effort to comprehensively review the literature on Education for Sustainable Consumption (ESC), with a focus on Waste Education and the inclusion of gender perspectives, to assess the most up to date research in the field.

The application of the tool ProKnow-C granted the identification and bibliometric analysis of 46 academic articles, which were distributed globally and intermittently, from 1990 to 2017. The central portion was published in 2016, and the most frequent publisher of such articles being the Procedia - Social and Behavioural Sciences journal. Also, all forms of education practices - formal, non-formal, and informal, were described, targeting school children, youth, urban communities, public administrations, and the private sector, and several research methods were applied.

The limited number of articles retrieved indicates on the one hand that the topics of ESC and waste education are under-exploited in the scientific research community, and on the other hand, that the search criteria selected might have limited the number of resulting publications. To address the former, more studies need to be undertaken, particularly on ESC themes other than the dominant Con-

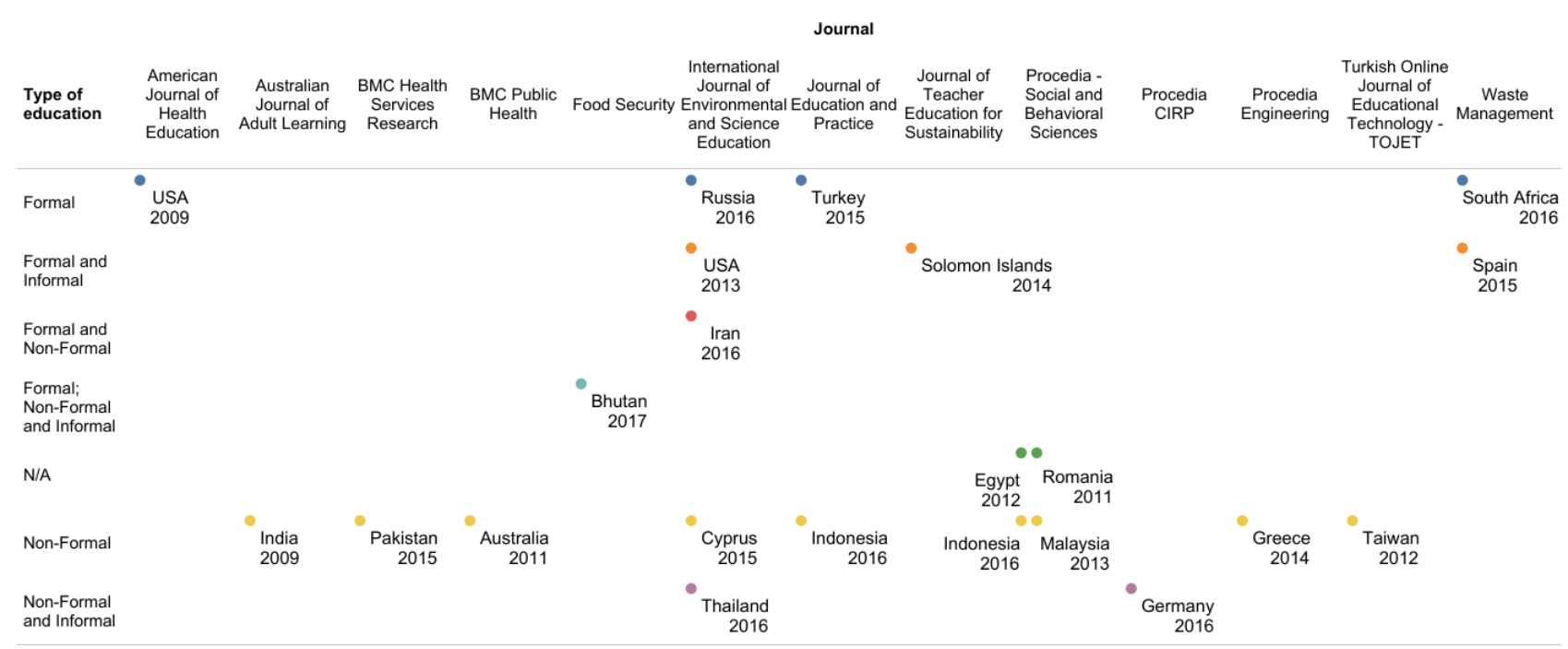

FIGURE 8: Summary of articles with gender perspectives' inclusion. 
sumption and the environment and Lifestyles; the latter issue can be tackled by modifying the search criteria to include, for example, articles that are not fully accessible online (limiting the study to abstract review), and by including grey literature.

On the review of gender perspectives, 22 out of 46 articles presented some form of inclusion of gender aspects. However, for the most part, gender was superficially addressed. For example, gender was often only mentioned in passing or solely to present sex-disaggregated data to describe the studied groups. Other identified issues, worthy of further research include the usage of gender-blind language and the inclusion of discourse that can potentially contribute to reinforcing gender stereotypes.

While there were cases of recognition and comprehensive consideration of gender into the research, these were limited, ultimately reflecting a need in the field of environmental education's research and practice, particularly in ESC and waste education, to expand on the topic and present ways towards the inclusion of gender perspectives. Accordingly, a follow-up study addressing this research and practice gap will explore the links between gender, waste, and education, and propose a framework for gender mainstreaming in waste education programs. The goal being, to harness the potential of gender inclusion for the effectiveness of the education programs, and for its contribution to gender equality.

\section{ACKNOWLEDGMENTS}

This study was supported by the Japan Society for the Promotion of Science, through its KAKENHI Grant Number JP17F17779. The authors also thank the anonymous reviewers of this manuscript and acknowledge the comments and suggestions from the participants of the 4th Symposium on Urban Mining and Circular Economy, held in Bergamo, Italy, 2018.

\section{REFERENCES}

Aguilar, L. (1999). A good start makes a better ending: Writing Proposals with a Gender Perspective (1a ed.). San José, Costa Rica.

Aikens, K., McKenzie, M., and Vaughter, P. (2016). Environmental and sustainability education policy research: a systematic review of methodological and thematic trends. Environmental Education Research, 22(3), 333-359. https://doi.org/10.1080/13504622.2015.1 135418

Autio, M., Heiskanen, E., and Heinonen, V. (2009). Narratives of 'green' consumers - the antihero, the environmental hero and the anarchist. Journal of Consumer Behaviour, 8(1), 40-53. https://doi. org/10.1002/cb.272

Avan, C., Aydinli, B., Bakar, F., and Alboga, Y. (2011). Preparing Attitude Scale to Define Students' Attitudes about Environment, Recycling, Plastic and Plastic Waste. International Electronic Journal of Environmental Education, 1(3), 179-191.

Blenkinsop, S., Piersol, L., and Sitka-Sage, M. D. D. (2017). Boys being boys: Eco-Double consciousness, splash violence, and environmental education. Journal of Environmental Education, 0(0), 1-7. https://doi.org/10.1080/00958964.2017.1364213

Brumby, S. A., Kennedy, A. J., Mellor, D., McCabe, M. P., Ricciardelli, L. A., Head, A., and Mercer-Grant, C. (2011). The Alcohol Intervention Training Program (AITP): A response to alcohol misuse in the farming community. BMC Public Health, 11(1), 242. https://doi. org/10.1186/1471-2458-11-242
Bulut, Z. A., Kökalan Çımrin, F., and Doğan, O. (2017). Gender, generation and sustainable consumption: Exploring the behaviour of consumers from Izmir, Turkey. International Journal of Consumer Studies, 41(6), 597-604. https://doi.org/10.1111/ijcs.12371

Caiado, R. G. G., de Freitas Dias, R., Mattos, L. V., Quelhas, O. L. G., and Leal Filho, W. (2017). Towards sustainable development through the perspective of eco-efficiency - A systematic literature review. Journal of Cleaner Production, 165, 890-904. https://doi. org/10.1016/j.jclepro.2017.07.166

Çelikler, D., and Harman, G. (2015). The Effect of the SCAMPER Technique in Raising Awareness Regarding the Collection and Utilization of Solid Waste. Journal of Education and Practice, 6(10), 149-159.

Chalfoun, N. (2014). Greening University Campus Buildings to Reduce Consumption and Emission while Fostering Hands-on Inquiry-based Education. Procedia Environmental Sciences, 20, 288297. https://doi.org/10.1016/j.proenv.2014.03.036

Chandra, D. V. (2014). Re-examining the importance of indigenous perspectives in the Western environmental education for sustainability: "from tribal to mainstream education." Journal of Teacher Education for Sustainability, 16(1), 117-127. https://doi.org/10.2478/ jtes-2014-0007

Chant, S. (2006). Re-thinking the "Feminization of Poverty" in Relation to Aggregate Gender Indices. Journal of Human Development, 7(2), 201-220. https://doi.org/10.1080/14649880600768538

Choi, M. Y., and Didham, R. J. (2009). Education for Sustaianable Consumption in Northeast Asia. Strategies to promote and advance sustainable consumption. Hayama, Japan.

Crawford, E. O., Luke, N., and Van Pelt, W. (2015). Children as "Solutionaries": Environmental Education as an Opportunity to Take Action. International Journal of Early Childhood Environmental Education, $3(1), 54-71$.

Crombie, I. K., and Davies, H. T. (2009). What Is Meta-analysis?

Danilane, L., and Marzano, G. (2014). Consumer Education in Primary School in the Context of Sustainable Development. Procedia - Social and Behavioral Sciences, 116, 1068-1072. https://doi. org/10.1016/j.sbspro.2014.01.347

Davis, G. (2008). Formulating an effective higher education curriculum for the Australian waste management sector. Waste Management, 28(10), 1868-1875. https://doi.org/10.1016/j.wasman.2007.12.003

Ekins, P., and Lemaire, X. (2012). Sustainable Consumption and Production for Poverty Eradication. Paris, France. Retrieved from www.unep.org/resourceefficiency

Ensslin, L., Dutra, A., Ensslin, S. R., Chaves, L. C., and Dezem, V. (2015). Research Process for Selecting a Theoretical Framework and Bibliometric Analysis of a Theme: Illustration for the Management of Customer Service in a Bank. Modern Economy, 6(June), 782-796.

European Institute for Gender Equality. (2016). Gender impact assessment: Gender Mainstreaming Toolkit. Luxembourg: Publications Office of the European Union. https://doi.org/10.2839/172256

Finlayson, C., Gregory, M., Ludtke, C., Meoli, C., and Ryan, M. (2017). Cultivating Geographical Thinking: A Framework for Student-Led Research on Food Waste. Review of International Geographical Education Online, 7(1), 80-93. Retrieved from http://www.rigeo.org/ vol7no1/Number1Spring/RIGEO-V7-N1-4.pdf

Garza-Reyes, J. A. (2015). Lean and green-a systematic review of the state of the art literature. Journal of Cleaner Production, 102, 1829. https://doi.org/10.1016/j.jclepro.2015.04.064

González-Gaudiano, É. (1990). Environmental Education and Sustainable Consumption: The Case of Mexico. Canadian Journal of Environmental Education, 4(1).

Gough, A. (2003). The "Nature" of Environmental Education Research From a Feminist Poststructuralist Viewpoint. Canadian Journal of Environmental Education, 8(March 2015), 31-43.

Gough, A. (2013). Researching Differently: Generating a Gender Agenda for Research in Environmental Education. In Robert B. Stevenson, M. Brody, J. Dillon, and A. E. J. Wals (Eds.), International Handbook of Research on Environmental Education (pp. 375-383). Routledge.

Gough, A. (2016). The Gendered City.

Gough, S., and Scott, W. (1999). Education and training for sustainable tourism: possibilities, problems and cautious first steps. Canadian Journal of Environmental Education, 4(1). Retrieved from http:// opus.bath.ac.uk/10730/ 
Hadiyanti, P. (2016). A Group Approach in a Community Empowerment : 9,2

Mostowfi, S., Mamaghani, N. K., and Khorramar, M. (2016). Designing playful learning by using educational board game for children in the age range of 7-12: (A case study: Recycling and waste separation education board game). International Journal of Environmental and Science Education, 11(12), 5453-5476.

Nagata, J., Azuma, T., Oda, N., Fujiwara, N., and Hanya, M. (2014). A mutual learning platform: A consumer-supplier collaboration experiment for low-carbon supply chain innovation. Energy Procedia, 61, 1752-1755. https://doi.org/10.1016/j.egypro.2014.12.204

Nowak, A. L. V., Hale, H., Lindholm, J., and Strausser, E. (2009). The Story of Stuff: Increasing Environmental Citizenship. American Journal of Health Education, 40(6), 346-354.

Oliver, S. (2016). Integrating role-play with case study and carbon footprint monitoring: A transformative approach to enhancing learners' social behavior for a more sustainable environment. International Journal of Environmental and Science Education, 11(6), 13231335. https://doi.org/10.12973/ijese.2016.346a

Organisation for Economic Co-operation and Development (OECD). (2005). The Role of National Qualifications Systems in Promoting Lifelong Learning, Report from Thematic Group 2 : Standards and quality assurance in qualifications with special reference to the recognition of non-formal and informal learning. Policy implications of national qualifications systems and their impact on lifelong learning.

Organisation for Economic Co-operation and Development (OECD). (2008). Gender and Sustainable Development: Maximising the Economic, Social and Environmental Role of Women. Environment: Science and Policy for Sustainable Development. Paris: OECD Publishing. https://doi.org/10.1787/9789264049901-en

Oto, N., Cobanoglu, N., and Geray, C. (2012). Education for Sustainable Airports. Procedia - Social and Behavioral Sciences, 47, 11641173. https://doi.org/10.1016/j.sbspro.2012.06.795

Painter, K., Thondhlana, G., and Kua, H. W. (2016). Food waste generation and potential interventions at Rhodes University, South Africa. Waste Management, 56, 491-497. https://doi.org/10.1016/j.wasman.2016.07.013

Palomo, J., Figueroa-Domecq, C., and Laguna, P. (2017). Women, peace and security state-of-art: a bibliometric analysis in social sciences based on SCOPUS database. Scientometrics, 113(1), 123-148. https://doi.org/10.1007/s11192-017-2484-x

Pankina, M. V., Khrustalyova, C. M., Egarmin, A. A., and Shekhova, N. V. (2016). Role of design in the consumer culture development: Ecological context. International Journal of Environmental and Science Education, 11(16), 8771. Retrieved from http://search. ebscohost.com/login.aspx?direct=trueandsite=eds-liveanddb=ericandAN=EJ1118961

Patterson, J., Lindén, E., Edward, J. K. P., Wilhelmsson, D., and Löfgren, I. (2009). Community-based environmental education in the fishing villages of Tuticorin and its role in conservation of the environment. Australian Journal of Adult Learning, 49(2), 384-395.

Pérez-Belis, V., Bovea, M. D., and Simó, A. (2015). Consumer behaviour and environmental education in the field of waste electrical and electronic toys: A Spanish case study. Waste Management, 36(2015), 277-288. https://doi.org/10.1016/j.wasman.2014.10.022

Polanec, B., Aberšek, B., and Glodež, S. (2013). Informal Education and Awareness of the Public in the field of Waste Management. Procedia - Social and Behavioral Sciences, 83, 107-111. https://doi. org/10.1016/j.sbspro.2013.06.021

QSR International Pty Ltd. (2017). What is NVivo? I NVivo. Retrieved September 18, 2018, from https://www.qsrinternational.com/nvivo/what-is-nvivo

Radulescu, D. M., and Radulescu, V. (2011). Educating the consumer about his right to a healthy environment. Procedia - Social and Behavioral Sciences, 15, 466-470. https://doi.org/10.1016/j.sbspro.2011.03.123

Redman, E. (2013). Advancing educational pedagogy for sustainability: Developing and implementing programs to transform behaviors. International Journal of Environmental and Science Education, 8(1), 1-34.

Ribas, J. R., Vicente, T. V. dos S., Altaf, J. G., and Troccoli, I. R. (2017). INTEGRAÇÃO DE AÇÕES NA GESTÃO SUSTENTÁVEL. Revista Eletrônica de Administração, 23(2), 31-57. https://doi.org/http:// dx.doi.org/10.1590/1413.2311.112.58086
Roeder, I., Scheibleger, M., and Stark, R. (2016). How to make people make a change - using social labelling for raising awareness on sustainable manufacturing. Procedia CIRP, 40, 359-364. https:// doi.org/10.1016/j.procir.2016.01.065

Rosa, P. A., Petri, S. M., Matos, L. dos S., Ensslin, S. R., and Ferreira, L. F. (2015). Avaliação de Desempenho no Planejamento Tributário: Aplicação do Processo Proknow-C em International Electronic Libraries. Revista Evidenciação Contábil and Finanças, 3(1), 69-83. https://doi.org/10.18405/recfin20150105

Ruini, L., Ciati, R., Marchelli, L., Rapetti, V., Pratesi, C. A., Redavid, E., and Vannuzzi, E. (2016). Using an Infographic Tool to Promote Healthier and More Sustainable Food Consumption: The Double Pyramid Model by Barilla Center for Food and Nutrition. Agriculture and Agricultural Science Procedia, 8, 482-488. https://doi.org/10.1016/j. aaspro.2016.02.049

Schreinemachers, P., Rai, B. B., Dorji, D., Chen, H. C., Dukpa, T., Thinley, N., ... Yang, R.-Y. (2017). School gardening in Bhutan: Evaluating outcomes and impact. Food Security, 9(3), 635-648. https://doi. org/10.1007/s12571-017-0673-3

Schultz, I., and Stieß, I. (2009). Policies to Promote Sustainable Consumption Patterns WP 1: "Gender aspects of sustainable consumption strategies and instruments." Frankfurt/Main.

Schulze, M., Nehler, H., Ottosson, M., and Thollander, P. (2016). Energy management in industry - A systematic review of previous findings and an integrative conceptual framework. Journal of Cleaner Production, 112, 3692-3708. https://doi.org/10.1016/j.jclepro.2015.06.060

Sexsmith, K. (2012). Towards Gender Equality in Global Sustainable Consumption and Production Agreements. In Harcourt W. (Ed.), Women Reclaiming Sustainable Livelihoods (pp. 4261). London: Palgrave Macmillan. https://doi.org/https://doi. org/10.1057/9781137022349_4

Stanszus, L., Fischer, D., Böhme, T., Frank, P., Fritzsche, J., Geiger, S., ... Schrader, U. (2017). Education for Sustainable Consumption through Mindfulness Training: Development of a Consumption-Specific Intervention. Journal of Teacher Education for Sustainability, 19(1), 5-21. https://doi.org/10.1515/jtes-2017-0001

Statistics Sweden. (2016). Monitoring the shift to sustainable consumption and Production patterns in the context of the SDGs. Retrieved from http://www.scpclearinghouse.org/upload/file_ management/file/170.pdf\%5Cnhttp://www.scpclearinghouse. org/news/188-advance-copy-of-paper-monitoring-the-shift-to-sustainable-consumption-and-production-patterns-in-the-context-ofthe-sdgs-.html

Stevens, C. (2010). Are Women the Key to Sustainable Development? (A. Najam, Ed.), Sustainable Development Insights. Boston.

Thoresen, V. W. (2010). HERE and NOW! Education for Sustainable Consumption: Recommendations and Guidelines. UNEP DTIE Sustainable Consumption and Production (SCP) Branch, 1-36. https://doi.org/DTI/1252/PA

Traversa, A., Adriano, D., Bellio, A., Bianchi, D. M., Gallina, S., Ippolito, C., ... Decastelli, L. (2017). Food safety and sustainable nutrition workshops: educational experiences for primary school children in Turin, Italy. Italian Journal of Food Safety, 6(1), 9-12. https://doi. org/10.4081/ijfs.2017.6177

UNESCO. (1999). Guidelines on Gender-Neutral Language. Retrieved from http://unesdoc.unesco.org/images/0011/001149/ $114950 \mathrm{mo} . \mathrm{pdf}$

UNESCO. (2007). The UN Decade of Education for Sustainable Development Report (The first two years). Paris, France: UNESCO. Retrieved from www.unesco.org/education/desd

UNESCO. (2014). UNESCO Roadmap for Implementing the Global Action Programme on Education for Sustainable Development. United Nations Educational, Scientific and Cultural Organization. Retrieved from www.unesco.org/open-ac- cess/terms-useccbyncsa-en

United Nations. (2016). SDGs: Sustainable Development Knowledge Platform. Retrieved September 18, 2018, from https://sustainabledevelopment.un.org/sdgs

United Nations Environment Programme (UNEP). (2010). ABC of SCP Clarifying Concepts on Sustainable Consumption and Production. Paris, France.

United Nations Environment Programme (UNEP). (2012). The global outlook on sustainable consumption and production policies: Taking action together. United Nations Environment Programme. 
United Nations Environment Programme (UNEP). (2016). Global Gender and Environment Outlook. Nairobi, Kenya: United Nations Environment Programme.

United Nations Environment Programme (UNEP). (2017). Consuming Differently, Consuming Sustainably: Behavioural Insights for Policymaking. Retrieved from http://www.greengrowthknowledge. org/sites/default/files/downloads/resource/UNEP_consuming_ sustainably_Behavioral_Insights.pdf

Viegas, C. V., Bond, A. J., Vaz, C. R., Borchardt, M., Pereira, G. M., Selig, P. M., and Varvakis, G. (2016). Critical attributes of Sustainability in Higher Education: A categorisation from literature review. Journal of Cleaner Production, 126, 260-276. https://doi.org/10.1016/j. jclepro.2016.02.106

Vieira, J. E. G., and Echeverria, A. R. (2007). A administraçao publica e a educaçao ambiental no Programa de Gestao Integrada de Residuos Solidos: uma reflexao de uma experiencia local. Cadernos EBAPE.BR, 5(1), 1-15.
Wahba, G. H. (2012). Latest Trends in Environmental Advertising Design "Application Study of Egyptian Society." Procedia - Social and Behavioral Sciences, 51, 901-907. https://doi.org/10.1016/j.sbspro.2012.08.261

Yang, J. C., Chien, K. H., and Liu, T. C. (2012). A Digital Game-Based Learning System for Energy Education: An Energy COnservation PET. Turkish Online Journal of Educational Technology - TOJET, 11(2), 27-37. Retrieved from http://search.ebscohost.com/login.aspx?direct=trueanddb=ericandAN=EJ989010andsite=ehost-liveandscope $=$ site

Zain, S. M., Basri, N. E. A., Mahmood, N. A., Basri, H., Yaacob, M., and Ahmad, M. (2013). Sustainable Education and Entrepreneurship Triggers Innovation Culture in 3R. Procedia - Social and Behavioral Sciences, 102(Ifee 2012), 128-133. https://doi.org/10.1016/j.sbspro.2013.10.723

Zarate, M. A., Slotnick, J., and Ramos, M. (2008). Capacity building in rural Guatemala by implementing a solid waste management program. Waste Management, 28(12), 2542-2551. https://doi. org/10.1016/j.wasman.2007.10.016 